\title{
Redefining Kurdishness in the U.S. Diaspora: The experiences of Kurdish Students and Their Parents in Nashville Schools
}

\author{
Demet Arpacik ${ }^{1}$
}

\author{
The Graduate Center of The City University of New York, USA
}

\begin{abstract}
As a result of a cumulative history of genocide, discrimination, and assimilation, Kurds have found refuge in many countries around the world, including the U.S., with the hope of practicing their culture and speaking their language without the fear of imprisonment or death. Unlike their fellow Kurds in the homeland, Kurdish people in the U.S. largely have the freedom to talk in Kurdish, dance, and sing in Kurdish, and dress Kurdish clothing. Kurdish people enjoy certain political and cultural freedoms in the U.S., which is largely absent in their homeland (Hassanpour, SkutnabKangas, \& Cyhet, 1996) but the on-going war on terror brings about new constraints and limits to these freedoms (Thangaraj, 2015b). This research aims to understand the dynamics of the Kurdish identity transformation and negotiations in the context of the U.S. diaspora and the role of educational institutions, as one of the primary spaces of encounter with the mainstream U.S. society, in this transformation. It seeks answers to how Kurdish students and their parents, as an inherently heterogeneous group, go through the complex process of negotiation of their identities in and through Nashville, Tennessee school system. It aims to understand the new struggles and possibilities that the Kurdish diaspora experience as they look for a place in the new society that has its own politics of identity. What does the information about Kurdish students and their parents' experiences tell us about the sociopolitical context of the new country and its racial, ethnic and gender relations and more specifically about the educational system as one of its institutions in reproducing these relations and placing Kurds somewhere in the spectrum of these relations? How does the case of Kurdish students and parents speak to the larger Middle Eastern diaspora studies?

Keywords; Kurdish Americans; The United States; Kurdish students; religion; identity; education
\end{abstract}

\section{Introduction}

Educational institutions are important sites of identity formations and reformations. They contribute, challenge, add and mostly perpetuate the already existing politics of identity and positions of the newcomers. Functioning like a social laboratory with people from diverse backgrounds, schools largely mirror the society. The societal discourses and relations around race, ethnicity, religion, gender, and class find expression in school settings. Through interviews with Kurdish students and their parents, this study plans to shed light onto the complex process of negotiation of Kurdishness in the new country as facilitated by educational institutions. Kurds' negotiation of their identity, as the present study will demonstrate, is multidirectional, complex, contested, and constantly evolving depending on the characteristics of each immigrant family, the social environment in which they live, the evolving politics of the host country or the countries from which they migrated from the Middle East, and the Kurds' representation in the eyes of the host country.

\section{Kurdish people}

Statelessness has been a determining feature of the Kurdish people and it has also largely determined their destiny. After the formation of nation states in early 1900s as a result of the collapse of the Ottoman Empire, the borders were drawn dividing the Kurdistan region into parts of four countries including Turkey,

${ }^{1}$ Correspondence; PhD. student in Urban Education at the Graduate Center of the City University of New York. E-mail; darpacik@gradcenter.edu 
Iran, Iraq, and Syria. Kurds have hitherto been systematically targeted by the dominant groups of the country they reside; they have been targeted for Arabization, Turkification, Persianification campaigns and their economic, social, cultural and political lives have been largely exploited in these nation-states. The resistance of Kurds to these policies gave way to immense atrocities, killings, genocides, deportation, forced migration, forced disappearances, village burnings, and the formation of a large diaspora all around the world.

Kurds are a very heterogeneous group in terms of religion, language, and culture. While the majority of Kurds are Sunni Muslim, there are also Shia, Alevi, Jewish, Zoroastrian, Yarsan, and Ezidi Kurds among others. Kurdish language is made up of at least four language varieties which are not mutually intelligible, namely: Kurmancî, Hawramî (Goranî), Soranî, and Zazakî. There are also numerous regional differences within these varieties (Hassanpour, 2012). Any effort to describe Kurds as a homogenous group both in their homeland or in diaspora will fail. Kurds' heterogeneity coupled with their stateless and transboundary reality renders a rigid definition of the Kurdish group impossible. While there is an imagined community of Kurds that one can talk about, to borrow the term from Benedict Anderson (1991), its experience and meaning is very contextual and transforms as the sociopolitical, economic structure of the society changes. What constitutes Kurdish identity is different in Kurdistan, even within Kurdistan, then in the United States.

This paper does not intend to use the term 'Kurdish' to refer to a homogenous group or ethnicity, it rather refers to a sociopolitical, historical, and economic reality of a group who identify as Kurdish and who get exposed to the material, social and psychological consequences of being so. The context of different diaspora experiences further transforms the Kurdish community. The term transnational identities serve well to understand the Kurdish diaspora and explain the reconstruction of Kurdishness between "two or more kinds of national or ethnic identities that emerge when people travel between different countries" (Bramadat \& Seljak, 2005, p.17). As is well stated by Braziel and Mannur (2003), the reality of diaspora "confounds the once clearly demarcated parameters of geography, national identity, and belonging" (p.1). Kurdish diaspora in Nashville, and in the U.S. in general, blur the boundaries of ethnicity, religion, and race even further as they recreate, redefine themselves, which makes their classification not a very neat process. Braziel and Mannur (2003) rightly argue, and this argument is highly relevant to the Kurdish case as a stateless group, that the diaspora reality is linked to effects of the nation-state formation and nationalism during and after WWII. The Kurdish diaspora is, largely, a result of this historical period during which Kurds were denied any right to self-determination or autonomy and they were left at the mercy of the nation-states. Kurds could not accomplish (!) the necessity of the new century-that is the establishment of a nation state, and therefore, the destiny of diaspora has largely been shaped by this reality as they fought for independence, cultural and political freedom in their new destinations to be in solidarity with fellow Kurds.

\section{Kurdish diaspora in Nashville, Tennessee}

Providing a very special case for the diaspora studies because of its worldwide migration pattern as well as the continuing resistance in its homeland, Kurds have been largely understudied until very recently in the area of diaspora studies. In particular, there has been scant to no research on the Kurdish diaspora in the U.S. with the exception of a few (Sheyholislami \& Sharifi, 2016; Thangaraj 2015b; Yigit \& Tatch, 2017). Nashville houses the country's largest Kurdish population and Kurdish students make up the city's third largest immigrant student group (Metro Government of Nashville, 2016; Nashville Public TV, 2012).

The migration of Kurds to the United States is quite a recent phenomenon. Both because of its small number and wide territorial dispersion, there exists very little scholarship based on these communities. The numbers of the Kurdish population in the U.S. is only estimated, and no official census has ever been conducted particularly because Kurds are classified in the nationality category of the states they are coming from (Kurds from Turkey, for instance, are registered as Turkish). While the total population of Kurds is written to be 15,361 according to 2006-2010 American Community Survey (U.S. Census Bureau, 2010), different sources give very different numbers. It is reported in different sources that there are larger Kurdish communities in Nashville, Tennessee (above 15.000) (Sawyer, 2017), who came mainly from Iraq starting from 1970s because of Saddam Hussein's war on Kurds. There are also Kurds in San Diego (above 10.000) and smaller number of Kurds in Georgia, Washington (DC), California, Minnesota, and the larger New England area. It is estimated that there are about 60.000 Kurds in the United States. There are also close to 12.000 Kurds in Canada according to Canada's official population census reports (Statistic Canada, 2011), but given the problem with statistics when it comes to the Kurdish population and the likelihood of increased Kurdish migration after the Syrian war, this number is probably much higher.

The majority of the Kurdish refugees did not come to the U.S. for the so-called 'American Dream', as noted by Nashville Public TV, "Kurds came to the USA fleeing genocide and oppression; like many 
refugees they sacrificed their former lives for new ones. They left their homes, their neighbors, and their culture in the search for security and survival" (2009). There have been four waves of Kurdish refugee settlements in the U.S. since 1976. The Kurdish refugees of the first wave came to the U.S. after the failure of the revolt for freedom in Iraqi Kurdistan. The Kurdish rebellion, which was initially supported by the USA and the Iranian regime, came to an end when Saddam Hussein reached an agreement with the Shah of Iran. The Kurds were left vulnerable to Saddam's attacks. As a result, thousands of Kurdish people escaped from the tragedy and some sought exile in the USA (Karimi, 2010). The second wave of immigration took place when Ayatollah Khomeini overthrew the Shah of Iran and created an Islamic Republic in 1979. Because of their opposition to the theocratic system, many Kurds left Iran and fled to the USA.

The third wave was the largest one, and in fact, the most tragic. Kurdish refugees of the third wave were the survivors of a genocidal campaign, known as Al-Anfal that was initiated by Saddam Hussein to eradicate all Kurds in Iraq. Al-Anfal campaign reached its peak in 1988 when civilians were gassed by chemical weapons in the Kurdish town of Halabja. According to the Human Rights Watch (1993), 50.000 to 100,000 Kurdish people were killed as a result of Al-Anfal campaign. Karimi writes that the number can be as high as 182.000 (2010). Thousands of Kurdish people crossed the borders to seek shelter; some later came to the USA after years of refuge in camps (Karimi, 2010).

The last wave took place in 1996. Kurdish refugees of this wave were mostly intellectuals whose lives were threatened by Saddam Hussein because of the support they were getting from the Western agencies. Two thousand people escaped from Iraqi Kurdistan overnight and were settled in Nashville (Nashville Public Television, 2009).

\section{Methodology}

This is a qualitative study that uses the method of open-ended interview. To have a thorough understanding of the effects of educational experiences on Kurdish families, both students and parents were interviewed, albeit with slightly different protocols geared to their roles, experiences, age, responsibilities, and perspectives. For each student interviewed, one of their parents was also interviewed. In total, 15 students and 15 of their parents participated. Of 15 parents, 2 were fathers and 13 were mothers. The reason for the higher representation of mothers is that mothers were usually the ones who had primary interaction with their students' schools and therefore had more insight. Majority of the families (13) who attended this study live in Nashville center. In particular, they live in the area on the southern tip of Nashville that is policed by the South Precinct. One family live in Brentwood, which is a wealthier suburb compared to Nashville and is 11 miles away from central Nashville and the other family live in Murfreesboro, which is 40 miles east of Nashville. However, both these families had lived in central Nashville for a long period of time and had only recently moved to their recent locations. The reason why I chose two families from different neighborhoods is to see the differences, if any, in schooling experiences of Kurdish students and their parents between areas that are more densely populated with Kurds and areas that are not.

Fourteen of the fifteen families had experiences of being refugees in Turkey. They spent between two to five years in the Turkish refugee camps before given asylum by the United States. The families were from Iranian Kurdistan (2), Turkey Kurdistan (2) and the rest were from Iraqi Kurdistan (11). Of fifteen families, fourteen came to the U.S. because of political reasons: war, revolution, and lack of freedom to exercise their culture. Most Kurdish families came in late 80s and early 90s during Iran-Iraq War. Fifteen families have lived in Nashville for at least 20 years, one family for 16 years and another for 14 years. Most parents were non-skilled workers when they came to the U.S. except the two families in which both parents had at least a university degree and the father in one of these two families was a university professor. All parents spoke some sort of English. Majority of mothers had difficulty communicating in English, but they were able to understand quite well.

Seven children were born in the U.S., one in Iran, two in Turkey, one during refuge in Turkey (from Iraq), and four in Iraq. Of the 15 children interviewed, 6 were boys and 9 were girls. The reason why there was a higher number of girls was that boys were usually away from home during the time of the interview, however, girls tended to stay at home with their parents and it was easier to arrange a time with them. Of 15 students, 4 were at middle school, 3 were at high school, 1 was high school graduate (aged 20), 5 were at college, and 2 were recent college graduates. Children were chosen from different grade levels to have a better idea of their experiences during different educational stages. I had initially started with middle and high school students, but I later leaned towards college students as they were better able to reflect on their experiences and had better understanding of the implications of their experiences on their identity formation and their place in the family and the society. 
As a self-identifying Kurdish female student, I was very much welcomed by the Kurdish community and this warm greeting facilitated the process of my data gathering. A Kurdish friend of mine from Iraqi Kurdistan introduced me to a Kurdish family (mother from Turkey Kurdistan and father from Iraqi Kurdistan) who hosted me in their house for about 2 weeks. The mother of the household, Züleyha (all names are pseudonyms), drove and accompanied me to most houses where interviews took place and she also actively searched for possible interlocutors. She has very generously given her time and attention to my project and I believe this has partially to do with the fact that we both were from the same town from Turkey Kurdistan, Batman. Most Kurdish families knew each other in some way. They were easily able to refer me to other potential participants in the process of "snowball sampling". The participants had a broad representation of Kurdish immigrants because they were from three of four regional parts of Kurdistan region (Turkey, Iran, and Iraq) - there were not many Syrian Kurds in Nashville at the time and I could not reach any (I am assuming their number increased after the intensification of the Syrian war in 2014). All parents preferred to be interviewed at home except 3 parents whom I met at Salahadeen Center, which serves both as a mosque and as a cultural center founded by Kurds and its name comes from the legendary Kurdish warrior, religious figure, and the founder of Ayyubid dynasty. Inclusion of parents who regularly attended Salahadeen Center for prayers and who were relatively more religious increased the representation of the sample because the level of religious practice and devotion within a family played a big role in the educational experiences of the family as evidenced in the findings of the study.

\section{Reflections on the politics of representation in Nashville schools}

When receiving immigrant populations, the first concern of the host country is around finding settlement and employment. Education of immigrants gets secondary attention (Verma, Kalekin-Fishman, \& Pitkänen, 2002; Ong, 2003; Tarman \& Gurel, 2018). While not considered as a priority in the immigration process, educational sphere is where the major negotiations of identity, culture, personality take place as immigrant children interact and socialize with others in a system geared towards educating 'the citizens of the country'. The educational institutions are one of the important sites where diaspora groups negotiate their identities. As multidimensional, contested, evolving, hybrid, and complex the Kurdish population is, the policies and practices of the school reveal a homogenous, static, stereotypical understanding of the Kurdish population. This section of the paper aims to understand the politics of representation in the school, its implications about the policies of the host country, and the effects of the type of representation on the identity of Kurdish communities.

With its inherent diversity, the urban schools in the United States demonstrate a babel of groups from various backgrounds. Multicultural education has been the most attractive term addressing diverse populations since late twentieth century in the U.S. which coincides with the Civil Rights era (Shankar, 2008). The separationist and overtly assimilationist approach was collectively challenged during the Civil Rights movement by the increasingly politicized populations who had been hitherto exploited. As the outspoken populations asked for equal rights, justice and reparation, the system looked for new forms of domination that were less visible and therefore more immune to change (Mauch \& Tarman, 2016). To contain dissent and facilitate domination in a more covert way, the politics of the conflict was culturalized and the systemic injustices were left largely untouched. The implication of this appropriation of dissent in the realm of education was the design of a unitary education with a multicultural lens (Carothers, 2018; McKereghan, 1998; Evans et al, 2018).

While many policy makers and educators have hastily advocated for multicultural education, critics argue that multiculturalism can serve merely as a façade to hide educational injustice and discrimination by the culturalization of social, political and economic problems of schooling. Kincheloe and Shirley (1997) argue that multiculturalism is practiced in ways that range from being conservative and monocultural to being critical according to the typology of multiculturalism that they developed. The most common understanding of multicultural education nowadays has been the pluralist multicultural approach - an approach that focuses on differences, celebrates diversity, advocates for equal opportunity, but largely dismiss structural injustices, systemic marginalization and macro policies of dispossession. Moreover, via this approach, the school perceives each immigrant group as homogenous, static, pure, exotic, different, and marginal; a group of people to be displayed and learned from to extend the understanding of diversity and to learn different ways of lives in the service for the dominant group which remains the norm (Boutelier, 2019; Ilyas, 2018).

Every student interviewee in this study talked about 'International day' when asked about their schools' practices that touched their sociopolitical, economic, historical and cultural realities. International day, as explained by students, takes place once a year during which students show their 'culture' through 
some displays such as artifacts, clothes, dance, and food. In all but two cases, this practice was not accompanied by any other supplementary practice to deepen the understanding of difference and to critically engage with this difference. Rather, the difference was taken at face value and celebrated. Shankar (2008) argues that diversity is only tolerated in the confined settings of school in the forms of cultural representation, which is seen as a collection of food, artifacts, cloth, dance, and music. This essentialist view obscures the sociopolitical dynamics, power relations, and identity politics. The international day was an 'addition' rather than 'part' of the regular program and school curriculum. This practice is a prime example of superficial and folkloric manner in which minorities are celebrated for their contribution to the diversity of the U.S. and serves no more than strengthening the already existing stereotypes and exotic, depoliticized understandings of diversity. The reductionist educational methods feed into stereotypical perception of Kurds and "tends to socio-political decontextualization of questions of race and gender and fails to problematize whiteness and Eurocentric norms" (Kincheloe \& Shirley, 1997, p.5).

While it is understood from the interviews that there is not any information in the curriculum regarding the Kurdish people, two teachers took personal initiatives and asked Kurdish students to 'explain their culture' briefly to their peers in the class. The effect of such presentations, while well intended, does not go further than enlarging the horizon of American students about other cultures to improve their cultural sensitivity and literacy, rather than situating the Kurds in a world history as one of many groups that influence and are influenced by the global issues. Moreover, the audience, in this case, peers, views this presentation as representing an entire people, culture or country whereby dismissing the complexity of a group's identity.

This form of representation reinforces hierarchies of "belonging" in that minorities are expected to explain themselves to the dominant group in the simplest form possible. Stuart Hall points out the ways in which minorities or the oppressed are "positioned and subjected in the dominant regimes of representation" through "exercise of cultural power and normalization" (Hall, 2003, p.236). He refers to Edward Said's theory of orientalism and argues that the non-white is categorized as "different and other" and further argues that every form of representation involves a form of power and a lens through which the image of the other is created in opposition to the dominant. In the case of Kurdish immigrants, the forms of representation do not only create an image of the "other", "foreign", but also "exotic", "static", "folkloric" people through the venue of multicultural education without any reference to their lived realities, histories, complexities and etc. Shankar (2008) argues that there is a systematic politics of representation in the schools' multicultural policies and activities that do not challenge the white hegemony. Shankar also defines such practices of "ethnic showcasing" as forms of consumption by students and faculty (p.122).

Kincheloe and Shirley (1997) expounds that "the focus of any cultural inquiry in a monoculturalist model involves exploring problems caused by social diversity and diverts the attention from racist, sexist, supremacist political system and its effects on the educational process" (p.4). While this paper does not intend to expand on the educational policies or analyze multicultural education, it aims to show how the current socalled multicultural schools can perpetuate societal prejudices and become a space where those prejudices are rearticulated, strengthened, and enacted. Kurds are no exception; they are also being subjected to such depersonalizing, depoliticizing and exoticizing practices.

It also seems from the Kurds' experiences with language issues that the school does not fully understand the linguistic diversity of the Kurdish community. Some schools had sent letters home in Bhadînî variety of Kurdish while the home variety was Soranî, or some students were given tests in Soranî variety that uses Arabic letters to Kurmancî speakers who use Latin alphabet. The school's minimal efforts in reaching out to Kurdish students and their parents or getting to know them remains rather superficial because of their simplistic approach. It is also rather intriguing that with more than 40 years of existence in Nashville, and being the third largest immigrant community, the Kurds are still not understood well in the school system. This situation may stem from the monolingual and monocultural stereotypical lens towards immigrants in general. According to monolingual perspective, people have one language or a standard language and the diglossia inherent in many communities is dismissed. In their attempts to fit their students into separate linguistic boxes and label them, schools are puzzled when they encounter the linguistic heterogeneity of Kurdish people. Because of the difficulty to categorize Kurds as just another immigrant group, schools' efforts to serve their diverse populations seem to remain ineffective.

\section{Increased centrality of religion with the new generation of Kurds}

Coming from a place where the majority of population is Muslim and where Kurds are predominantly Muslim, religion is not a strong decisive factor in distinguishing the Kurds from other Middle Easterners in their home countries, however it has gained increased salience and importance for the new 
generation of Kurds who have been exposed to the politics of religious identity in the U.S. The U.S. operates different identity politics, compared to the countries where Kurds came from, and the accompanying social stratification is highly deterministic (Thangaraj, 2015a; Joshi, 2006). There were some ready labels to be ascribed to Kurds in the new land: Muslim and Middle Eastern (Rana, 2011).

Religion, for which no direct questions were posed in the open-ended interview protocols (I admit this to be my own blindness), has evolved as the most central and consistent theme of the data I gathered from the interviews. Islamophobia and related stereotypes were expressed in both students' and parents' interviews as being an important aspect shaping the experiences of Kurdish students and their relations with peers in schools. While both parents and students stressed the importance of their religion and its central place in their lives, some differences between parents and students were speaking the changing nature of the relationship that each generation has with religion. In some families, religiosity was higher with students, the new generation, than their parents, the old generation (see also, Peek, 2010). While this was not the case with every parent-student, it was something that was noted frequently. Both Baran, 20-year-old male high school graduate (family from Kurdistan of Iraq), and Peshraw, 20-yearl-old male college student (family from Kurdistan of Iran), stated that they would like their parents to be more religious and pray more. Peshraw's father, Hassan, was a patriotic Kurd and Kurdishness was the central identity construct for him. He started his interview saying that he lives and will die for Kurdistan. He also wanted to be a good citizen of the U.S. to pay off his gratitude for it that provided him shelter amidst atrocities. For Peshraw, different from his father, religion was the central aspect of his identity and he put it before his Kurdish identity. He was the head of Muslim Student Association in his university. Peshraw stated that he was more religious than both of his parents and he even expressed his wish to teach his parents more about religion. He expressed his ideas about his parents' religiosity as:

My dad is less religious than me. My mom prays traditionally; she did not even know what she was saying during the pray was Arabic, she thought it was Kurdish that she would not understand. I wish I could explain religion to my mom and dad. We differ in our thinking. The way my father thinks of Islam is very similar to Americans' thinking of Islam. Every news coming out about Muslim groups increases this divide. My father says that they (Muslims) do not deserve to live here. He is spiritual but not religious.

As is seen in the last sentence, Peshraw does not even view his dad as religious, but instead spiritual. Peshraw did not get a religious education from his parents, except the fact that his father tried to teach him how to pray for one time. Especially after 9/11, he, together with other Kurds and the larger Muslim community, faced Islamophobic attacks. He was constantly being asked about why he was a Muslim and got many questions about Islam. He did not know much about his religion in high school. As expressed by all interviewees, there is no information about Islam in schools, even when it comes to what is written briefly about it in the textbooks, teachers tend to skip, students stated. Ongoing questions made Peshraw get curious about his religion. He initially used the internet to learn more about his religion and his knowledge increased when he was later approached by other non-Kurdish Muslim students from his university and was taught more about Islam ${ }^{2}$. Baran, similar to Peshraw, was also troubled by the fact that his parents were not practicing their religion. He stated, "I would like to make my parents more religious. My parents don't do nothing. I just want them to practice more. After high school I realized that nothing is better and more beneficial than your religion... Your culture will not benefit you as your religion. When you die, God will not ask you what your culture is."

There are two analyses to be made regarding Peshraw and Baran, but also about other students who stressed their Muslim identity being more salient when asked if they would describe themselves as Muslim or Kurdish first. Religion already constitutes a key element of difference between Kurdish students and their native-born American peers. The studies show that younger generation Muslim immigrants are more likely to strongly identify with their Muslim identity than their parents in the U.S. (Wang, 2013). Another issue to note here to better understand the increasing religiosity among the new generation is the pan-ethnic element in their arguments. Bakalian and Bozorgmehr (2009) argue that structural conditions such as racism, misrepresentation, violation of rights, and xenophobia can bring some groups together who can identify with a larger framework (in this case Muslim and Middle Eastern) than their more particular characteristics such

${ }^{2}$ For information about diasporas and Islamic education, see Grewal, Z. (2013). Islam is a foreign country: American Muslims and the global crisis of authority. 
as ethnicity or language (Kurdish ethnicity and Kurdish language). The new generation can develop an identity that is pan-ethnic, Middle Eastern Muslim, or Muslim in general, transcending the boundaries of ethnicity, something what anthropologist Ahmed Afzal (2014) labels as a "Muslim heritage economy." This does not claim that students forget their Kurdish identity, in fact they are very vocal about it, yet in the meantime, they develop a sense of common faith with others from different ethnic backgrounds around the need to associate in some level to resist the structural conditions together as a way of "pan ethnicmobilization" (Bakalian and Bozorgmehr, 2009, p. 13).

The stereotypical understanding of Kurds as violent Middle Eastern Muslims has been revealed in unexpected instances in school. Rebar's experience, as a 16-year-old male high school student, epitomizes this long-held stereotype. Rebar was interested in creating new tech, fixing computers and electronics. One day he created a device with a CD-ROM and attached a button in the middle, which was making the device illuminate. As he was showing his device in the class and tried to press the button, the teacher stopped him, and everyone together with the teacher screamed because people thought it was a bomb. Taken to the administration, the principal forcefully got his device from his hand and called his family. Rebar said that people later learnt that the device was not a bomb and they apologized, but he thinks that this case happened because of his religious identity and because how other people view Muslims. After this case, Rebar's White American mother (who converted to Islam after marrying her Kurdish husband) decided to take him from school and homeschool him. At the time of my interview, Rebar was being homeschooled.

Religion cannot be analyzed in isolation from the ethnicity of Kurds; they are entwined especially in a place where Muslim identity becomes salient. Smith and Grodz (2014) argue that religion and ethnicity are not two independent constructs developing in isolation from each other. Ethnicity and religion are in dialogical relationship. The religious rituals, symbols can be used to "boost ethnic identity" (Smith \& Grodz, 2014, p.17). Ethnicity is also more likely to be preserved if the immigrant group practices their religion especially when their religion is linked to their ethnicity (Hammond, 1998). This complex two-way relationship between religion and ethnicity also comes to surface during interviews with Kurdish parents and students. $7^{\text {th }}$ grade high school male student Ciwan's explanation of his inability to join his schoolmates' parties shows the inseparability of ethnicity and religion as he uses these terms interchangeably. He states;

When everybody would go swimming, they would have parties. They would always invite me. Sometimes I give up. I say I wish I was not Kurdish; I would go and hang out with them because they have so much fun. But because of my ethnicity my parents would not like me to go and they would not like me to change into theirs. Yes, I am very religious too. That is my problem. I try to involve in their ethnicity too, my religion stops me doing it. I cannot go to parties and socialize with females as they do.

Some Muslims or Kurds may disagree that not going to parties is not a religious or ethnic thing, however in Ciwan's perception it is. For him there is a sense of unified identity that involves both religion and ethnicity. Stuart Hall (2003), who contributed immensely to a deconstructivist understanding of identity argues that, "we cannot speak, with any exaction about 'one experience, one identity' without acknowledging its other side" (p.240). To speak of Kurds as only Muslim or only Kurds will largely underestimate the complex relational identities they develop especially in diaspora contexts.

Ciwan's mother, Hanim, also views religion and ethnicity as interlinked. Ciwan's struggle to stick to his culture coupled with his temptation to engage with his friends is also expressed and recognized in his mother's words;

Working and taking care of teenagers... It is hard because they are between two religions and two different cultures. They go to school they learn something else from different cultures, religions, and people. When they come home, we have another religion, culture and language. We try to keep them on our religion, that is my point. It is too hard because every day they have a lot of questions. Why they do that why we do this; why they can do that, why we cannot do this. We have to teach them and explain to them that we are different; we are from a different country. We have different culture and religion. 
Similar articulations, connections, and contradictions highlight the struggle of Kurds in responding to the new codes, lifeworlds and understandings within the diasporic spaces in Nashville. The new generation invents creative ways to bridge these gaps between who they and their families believe they are and should behave like and how they perceive the society to be like. In their efforts to comply with their culture and religion and to simultaneously fit into the society, the Kurdish youth creatively transforms the new and the old ways and create new realities, the same is true for parents. An example can help to illustrate this analysis: Nashville is a famous city for its nightlife with bars and live music. However, nightlife was also something that frequently came up in the interviews especially by parents as something to refrain from. 20 -year-old male university student Namo, stated, "it is hard for parents to understand some things. Sometimes I hang out outside till $3 \mathrm{am}$. They think that we are doing bad things. We are not, we are smoking hookah, talking about religion and school, they think we are kind of in trouble or something". Namo enjoys the nightlife, which is part of the city culture, but he does it in a way to also comply with the rules of home, religion, and culture by going to a hookah bar that sets a different perception of nightlife for him. Namo's attempt in creating new spaces for himself that avoids disrupting the home culture but seeks to engage with the city's culture, illustrates the competing notions of Kurdish identity in the new space and the resultant regulation of various aspects of Kurdishness to adapt to the new life. Being a Muslim and a Kurd in a place where these identities are minoritized, Kurdish youth negotiates and reconstructs new meanings that give them both a unique identity and place, in relation to the dominant group and other minority groups, and also an identity that partially adapts to the dominant norms and life-worlds.

Smith and Grodz (2014) posit that migrants' relation with religion is more complex than merely becoming more or less religious. In fact, for migrants, religious beliefs and structures serve as a support mechanism to cope with the challenges they face in their new contexts. In the new world where there are many crises of adaptation and the possibility of a very dangerous and violent life outside home, religion serves as a safe and educational space for parents to raise their children and for students to find meaning and identity in their lives in addition to other ways of identification sources such as gangs. Many parents raised concerns about their children's involvement in what they considered as bad behaviors, which can be summed up as hanging out at the nightclubs, doing drugs, adultery, being deceived by peers for involvement in violence and gangs, and leaving the family. For some, religion was a way to protect their children from these situations and served as an educational medium, yet they were also worried about radical Islam and feared that their peers may deceive and radicalize their children. In fact, some students have also expressed similar sentiments as their parents. A male college student, Namo, expressed his attachment to religion as, "nothing before made us satisfied except our religion. Religion is a way to stay away from trouble". In the process, we see how Islam becomes a site of education and subjectification among generations.

\section{The challenge of 'good and bad immigrant' discourse}

The concepts of freedom of speech, diversity and multiculturalism are highly celebrated in the U.S. context, but they assume a non-problematic and successful integration of diversity and do not necessarily reflect outcomes of complex encounters of diverse groups, identity politics, and resulting issues such as xenophobia, and other sorts of intolerance as well as structural racism and systemic issues. As stated earlier, different racial, religious, and economic dynamics of the U.S. produces new dilemmas for the Kurdish identity development. Religion plays a more central role in shaping the experiences of Kurds and their relations with others in the new society. Therefore, it is crucial to focus on how Kurdishness and its relation to religion is being redefined in the new society that has its own codes of identification and imposes these upon the new groups.

Described as a country of immigrants, the U.S. has a categorizing discourse of "good and bad immigrant" (Thangaraj, 2015b). Muslim immigrants are categorized twice based on this logic by the binary of "good and bad Muslims" (Mamdani, 2002). Kurdish diaspora is not immune from the effects of these discourses towards immigrant Muslims. They are reminded in various ways that there is a model of a good Muslim immigrant and those who don't confirm to this category suffer the consequences. The Nashville Public Television created a small documentary entitled Little Kurdistan about the Kurdish diaspora living in Tennessee in 2009, a year after the detention of two Kurdish Pride Gang Leaders (KPG). The documentary was mainly an introductory film to introduce Kurds to the larger American people of Nashville, but the motivation behind was very likely to alleviate the bad image that was ascribed to the Kurdish immigrants due to KPG. The documentary stresses that KPG was an unfortunate happening and it is the job of some bad young people, not related to the larger hard-working Kurdish community that holds strong work ethics. While the documentary does a relatively good job in portraying the complexities of Kurdish community, it certainly reveals its political agenda with regards to the Muslim immigrants in the U.S. The way that the documentary 
portrays Kurds very much aligns with the country's model of the "good immigrants", those who keep practicing customs, traditions of their culture, but submit to the societal expectations of being hard-working, willing to adapt to the mainstream culture, being thankful to the host country, and taking pride in it. Aiming to serve as an educational medium for the dominant population, the documentary has its own pitfalls. The documentary is narrated by a non-Kurdish, perhaps white American male, suggesting the gaze of the dominant group. It depoliticizes the very political formation of the Kurdish Pride Gang and its historicity. It also clears the dominant Nashville society from any possible critique by portraying the issue of gang as 'inherent to immigrant populations' rather than an outcome of deracinating socioeconomic and political conditions in the U.S. that render these populations vulnerable and prone to violence.

In line with the "good immigrant" discourse, the documentary Little Kurdistan also stresses that Kurds' did not have a difficult time integrating into the American society because they had strong family ethics and were hard-working people, indirectly implying that these values already exist in the American society. The documentary also illustrates how Kurdish people created their own community called Little Kurdistan in order to preserve their cultural heritage. Bakalian (1993) states that this dual identity, that is the dual process of ethnicization and Americanization, is an encouraged notion in the U.S., which leads to what she calls "hyphenated American". One of the Kurdish woman interviewees in the documentary, Kasar Abdullah, who is 28-year-old women covering her hair, later received the White House award of the Champions of Change in 2013. The reason for the award is written on the White House Website as "working tirelessly to effectively integrate immigrants civically, linguistically, and socially into the fabric of their neighborhoods". The discourse of good Muslim immigrant, this time, is being rewritten through the example of Kurdish community. While Kasar Abdullah is seen to be a very powerful woman, like many other immigrant women, deserving recognition, her resilience is being appropriated to be fed into dominant narrative of 'good immigrant' who still embodies 'beautiful, colorful ethnic' culture all the while conforming to dominant linguistic, cultural, and economic codes. These moments of recognition involve an interesting weaving together of religion and race in the racialization of the Middle Eastern and Muslim American communities (Rana, 2011; Alsultany, 2012).

This discourse is not unique to Nashville, Tennessee, but rather is widely expressed in the wider U.S. The seasonal e-journal of the Bureau of the International Information Programs of the U.S. Department of State confirms good immigrant expectation in the journal published in 2008 entitled Immigrants Joining the Mainstream with a cover photo of people of different colors in suits and professional dresses (2008). There is a short article in the journal with the title Good Immigrant Student that tells the success story of an immigrant who is described as "a little girl born in Vietnam learns to be American". She becomes American when she becomes a professor at a good university. Both her Vietnamese origin and her now American side are highly praised to comply with the standards of a "good immigrant".

Kurdish students are cautious to be regarded as radical Muslims because right after 9/11, they faced immense stigmatization, xenophobic, racist, and Islamophobic attacks. Of the 15 students, 13 stated that they were interpellated by the word 'terrorist' mostly by their peers in the school simply because of being Muslim. Hozan stated that this situation got worse after $9 / 11$ and continued, "I felt separated afterward, especially after 9/11. Some students in school would make fun of us, push us, and ask questions like why we are Muslim". This situation does not only affect students who are practicing religion, but also those who do not. 19-yearold male college freshman, Zana, expressed this resentment as, "I do not like people's attitude towards Middle Easterners, especially after $9 / 11$. This is really annoying. If you are from a Muslim family, it makes you automatically terrorist and that really makes me sad. I call myself Muslim, but I do not really practice".

Peshraw stated that the attacks after 9/11 helped Kurds get closer. Racist attacks on Kurds as a result of the post-9/11 racial hysteria was so frequent and intense that the Kurdish youth started to organize to protect themselves. The need for protection is also expressed by Namo, "stick to your own kind, so you won't get in trouble. In high school, it was bad, fighting-wise, gang-wise, so people would stick to their people. If you mess with them, they would protect you too. Teenagers would have gangs; they would involve in bad staff. Since we came here, Kurds adapted life here too". The school was the primary place where Kurdish students were marginalized based on their religious background and they did not have a support program to protect themselves against Islamophobic and xenophobic attacks. One of the results of this stigmatization on Kurdish youth after 9/11 was the establishment of the Kurdish Pride Gang (KPG) in early 2000s.

The gang consisted of a couple hundred members in early 2000s. Majority of its members joined the group when they are in high school. First established to protect themselves from attacks in the educational settings, the youth soon involved in fights with other gangs, drug trafficking, and finally murder. Nashville, with its strategic location in the Midwest, is a key site of the movement of drugs and drug-related paraphernalia and this condition also fed into the transformation of KRG from a high school gang founded to 
protect against bullying and racism to one engaged in illegal activities and violence. Baran stated that during its peak, KPG occupied a public park in the middle of Nashville and the police was not able to enter the park for a long time. The emergence of Kurdish Pride Gang further stigmatized Kurds, this time not only as Muslim terrorists, but also as violent Kurds with local dangerous networks. After the arrest of two brothers who were claimed to be the gang leaders in 2008, KPG has not been active for a long time and most likely entirely dissolved today. Peshraw, whose two cousins (now in prison) were the founding members of KPG, explains KPG's motivation and development:

I have two cousins who are in prison right now. They had records, one for 10 years and one for 35 years. This was after 9/11. Kurds came together to fight all this discrimination against Muslims and Kurds. They would hang out in parks and listen to bad music. After that, they involved in bad things rather than going home. They turned into having drugs, guns... They involved in fights with other gangs. They were charged with attempted murder. My cousins were 20 and 28-years-old when put in jail. After that people started to think of Kurds as gangsters, just like people think of Muslims as terrorists. My cousins changed their perspective in the jail, they are regretful and read Qur'an everyday now, but they cannot get out.

Brotherton and Barrios (2004) calls gangs as street organizations and define them as, "a group formed largely by youth and adults members of a marginalized social class which aims to provide its members with a resistant identity, an opportunity to be individually and collectively empowered, a voice to speak back to and challenge the dominant culture" (p. 23). KPG, as Peshraw and Namo stated, also grew out of desperation and the need to protect themselves. Once described as terrorists, Kurds were now also viewed as gangsters-localized racialized term to mark difference. Some Kurdish students have felt that their teachers were acting as if all Kurds were gangsters during the active times of KPG. Ravin, a 17-year-old female high school student, had been exposed to scary eyes in her school when others learned she was Kurdish. She expressed her feelings saying:

There was this one point when Kurds would get into trouble and others would say they are all gangsters. I did not let them discourage me. It was kind of racist when they would say all Kurdish people are like this.

Hozan, 19-year-old male high school graduate, noted that when his teachers see a few Kurds coming together, they react and follow them assuming an involvement in gangs. He feels that because he is Kurdish, teachers tend to have an impression that he has a propensity for bad, ruthless behaviors. Misrepresentation coupled with already existing segregation in the school further increases the stereotypes. Almost all students (11) expressed their experiences with various degrees of segregation in their schools with peer relations because of religious and ethnic differences. Ravin noted this change as:

At first my friends were very diverse, but towards high school I started to hang out more with the Kurdish people. Even in the hallways you would see that there was an area where only Caucasians would hang out or only Kurds.

Namo explained this increasing segregation, "as you get high school, people separate. People would stick to their kind of people. Kurds would stick to Kurds. This is because of trust. If you stick to your own kind, you will not get in trouble." While I did not touch upon militarism and its feeding violence within school settings, these experiences are strongly related to the already existing forms of racial and socio-economic violence of all sorts in the society that find articulation in school settings. The ongoing racialization process of the religious identities together with the U.S.'s involvement in the policies of the Middle East, the existence of other Middle Eastern immigrants in the U.S. and the related depiction of the Middle Eastern people in the media as the violent enemy and terrorist (Alsultany 2012; Puar, 2007), creates further implications for the experiences of the Kurdish population, as is evidenced in my findings. Certain societal prejudices and stigmas about Kurds or the Middle Easterners in general, can easily find ground in school settings where learning about different cultures are not supported with a critical lens that looks at the power relations, structural injustices and politics of representation. 
Extracurricular activities, which are related to schooling, such as sports, function as a site of conflicting identity politics. Kurdish students, who do not fit into black-white racial binary, try to find a space for themselves to insert their own identity "through various consumptive practices of popular cultures", sports being one of them (Thangaraj, 2015a; 2013). 16- year-old high school male student Ciwan's experiences, as he tried to involve in some kind of sportive activity, is an example of how Kurdish identity is negotiated through sports, that is "policed at the intersections of race, ethnicity, religion, gender, and sexuality" (Thangaraj, 2015a). Ciwan stated (male, $7^{\text {th }}$ grade): "I tried basketball. They told me 'hey you are Kurdish, this is black sports. When I tried football, they told me 'you are Kurdish, go play soccer'. Now I play soccer”. Not only that Ciwan's experience illustrates the racial dynamics in sports activities and its educational ties, it also shows how social prejudices and stereotypes determine the options available for the members of a certain group. Ciwan's preference as a person was secondary to his perception by outsiders, which determined the opportunities available to him as a Kurd.

The multiplicity of diasporic experiences affects the functions and purposes of religion and religious institutions. The functioning of the religious center, Salahadeen Center, for instance, is an example of this situation. While in the Middle East, a mosque mainly and almost exclusively serves as a place to pray (mostly for men, yet also for women on special occasions in a separate section of the mosque), it serves a much larger function for the immigrant communities in the new context. This changing situation is not novel to the Kurdish population and is a practice common to immigrant populations. For instance, in a similar study with Muslims in Canada, it was noted that the roles of Imam and the nature of the mosque was changing in relation to the similar existing systems of operation such as priesthood and church (Bramadat, \& Seljak, 2005; Woofter, 2019). Similar to the Canadian example, Kurdish mosque in Nashville serves as a cultural center in addition to a religious center as well as a site to negotiate the polarity of Americanness and Kurdishness. It provides a variety of religious and educational opportunities. Having a Facebook page of its own, which is not quite observed in mosques in Kurdistan, Salahadeen Center is described as providing "social services, education and religious organization". The center invites religious leaders for talks, gives weekend classes for kids to learn religion, and helps with immigration process and serves as a space for Muslims, mainly Kurds, to come and meet each other and shop at nearby Kurdish supermarkets. Moreover, unlike many mosques in the Middle East, women pray on Fridays as a group at Salahadeen Center. Mosque becomes a site of education that does not cause religious marginalization unlike the mainstream educational classroom. This case shows how the meaning and understanding of religion and its rituals is reconfigured as a consequence of new challenges and possibilities that immigrants are exposed to in the new destination.

\section{Conclusion}

This analysis points out the centrality of educational experiences of the Kurdish diaspora in Nashville, Tennessee in their identity development which is constantly evolving. Kurds' racialization as Muslim immigrants affects their perception of themselves and the activities they are engaged in. Their experiences of exclusion foster a pan-ethnic mobilization as Muslims in addition to Kurdish in both educational and non-educational settings. Their racialization as Muslims in the new context and subsequent stigmatization and Islamophobic attacks pull Kurds into a defense position where they have to protect, prove and preserve themselves. It reads from the experiences of Kurdish students and their parents that schools are not neutral grounds but ideological spaces where the dominant culture exerts its hegemony on the minority, on the one hand, to push for assimilation, and on the other, to perpetuate exclusion. This contradictory looking approach gives a clear message to Kurds that they are at the periphery. This study elaborated on some challenges that Kurdish students and their parents experience as they negotiate in the new society with educational institutions as crucial sites in this process. The simplistic and orientalizing understanding of diversity as an educational philosophy in the context of Nashville schools obscures the complexity of Kurdish as well as other identities and leads to exotic and otherizing representations of migrant communities in schools in the forms of food, cloth, dance, and music during international days. Multicultural education with a lack of critical lens fosters stereotypical understanding of minorities leading to their marginalization. It also leavesunjust practices, systemic issues and racism intact.

Through a critical examination of education and diasporic settings, we are able to conceptualize the ways that education becomes a contested and polyvalent site for imagining not only individuals and communities but also the nation. While education has been one key site of violence against Kurds in Turkey, Syria, Iraq, and Iran, the diasporic experiences offers us many ways to see how education provides a transnational scale to manage experiences in Kurdistan alongside the lived experiences of race in Nashville, TN. 


\section{References}

Afzal, A. (2014). Lone star Muslims: Transnational lives and the South Asian experience in Texas. New York, NY: New York University Press.

Alsultany, E. (2012). Arabs and Muslims in the media: Race and representation after 9/11. New York, NY: New York University Press.

Anderson, B. R. (1991). Imagined communities: Reflections on the origin and spread of nationalism. London, England: Verso.

Bakalian, A. P. (1993). Armenian-Americans: From being to feeling Armenian. New Brunswick, Canada: Transaction. http://dx.doi.org/10.4324/9781315082127

Bakalian, A., \& Bozorgmehr, M. (2009). Backlash 9/11: Middle Eastern and Muslim Americans Respond. Los Angeles, CA: Univ of California Press.

Boutelier, S. (2019). Limiting Learning Environments through Domestication. Journal of Culture and Values in Education, 2(1), 45-55. Retrieved from http://cultureandvalues.org/index.php/JCV/article/view/29

Bureau of the International Information Programs of the U.S. Department of State (2008). Immigrants joining the mainstream 13 (2). The Author. Retrieved from http://photos.state.gov /libraries/amgov/30145/publications-english/EJ-immigrants-mainstream-0208.pdf

Bramadat, P., \& Seljak, D. (2005). Religion and ethnicity in Canada. Toronto: Pearson Longman.

Braziel, J. E., \& Mannur, A. (2003). Theorizing diaspora: A reader. Malden, MA: Blackwell Pub.

Brotherton, D., \& Barrios, L. (2004). The Almighty Latin King and Queen Nation: Street politics and the transformation of a New York City gang. New York, NY: Columbia University Press.

Carothers, D. (2018). A culture of equality?. Journal of Culture and Values in Education, 1(2), 42-57.

Retrieved from http://cultureandvalues.org/index.php/JCV/article/view/13

Evans, K., Russell, W., Furgione, B., \& Sheridan, A. (2018). "Won’t You be my Neighbor?, Journal of Culture and Values in Education, 1(2), 1-22. Retrieved from http://cultureandvalues.org/index.php/JCV/article/view/7

Grewal, Z. (2013). Islam is a foreign country: American Muslims and the global crisis of authority. New York, NY: New York University Press.

Hale, J. (2016). The Freedom Schools: Student activists in the Mississippi civil rights movement. New York, NY: Columbia University Press.

Hall, S. (2003). Cultural identity and diaspora. J. E, Braziel, \& A. Mannur, (Eds). Theorizing diaspora: A reader (233-247). Malden, MA: Blackwell Pub.

Hammond, P. E. (1988). Religion and persistence of identity. Journal for the Scientific Study of Religion 12, 1-11. http://dx.doi.org/10.2307/1387398

Hassanpur, A. (2012). The indivisibility of the nation and its linguistic divisions. International Journal of the Sociology of Language 2012 (217), 49-73. http://dx.doi.org/10.1515/ijsl-2012-0049

Hassanpour, A., Skutnab- Kangas, T., \& Cyhet, M. (2006). The non-education of Kurds: A Kurdish perspective. International Review of Education, 42 (4), 367-379. http://dx.doi.org/10.1007/ BF00601097

Black, G. (1993). Genocide in Iraq: the Anfal campaign against the Kurds. Human Rights Watch. New York, NY: Author.

Ilyas, M. (2018). Expatriate Experience and the Fictional World of Diaspora. Journal of Social Studies Education Research, 9 (1), 106-123. Retrieved from http://dergipark.org.tr/jsser/issue/37945/438319

Joshi, K. Y. (2006). The racialization of Hinduism, Islam, and Sikhism in the United States. Equity \& Excellence in Education, 39(3), 211-226. http://dx.doi.org/10.1080/10665680600790327

Karimi, H., (2010). The Kurdish immigrant experience and a growing American community. Kurdish Herald, 2 (1). Retrieved from http://www.kurdishherald.com/issue/v002/001/article04.php

Steinberg, S. R., \& Kincheloe, J. L. (1997). Changing multiculturalism: New times new curriculum. London, England: Open University Press.

Mamdani, M. (2002). Good Muslim, bad Muslim: A political perspective on culture and terrorism. American Anthropologist, 104(3), 766-775. http://dx.doi.org/10.1525/aa.2002.104.3.766

Mauch, J., \& Tarman, B. (2016). A historical approach to social studies laboratory method. Research in Social Sciences and Technology, 1(2), 55-66. 
https://doi.org/10.29333/ejecs/252

McKereghan, D. L. (1998). Cultural Diversity and Ethnocentrism: Moral Problems for American Public Education (Doctoral dissertation, Gonzaga University).

Metro Government of Nashville. (2016). Mayor's office of new Americans. Retrieved from http://www.nashville.gov/Mayors-Office/Neighborhoods/New-Americans.aspx

Nashville Public TV. (2009). Next door neighbors: Little Kurdistan. Nashville, TN: The Author.

Nashville Public TV (2012, October 15). NPT Reports: Kurdish community tries to bridge cultural gap wit. Retrieved from http://www.nptinternal.org/nptreports/2012/10/15/npt -reports-kurdish-communitytries-to-bridge-cultural-gap-with-schools/.

Ong, A. (2003). Buddha is hiding: Refugees, citizenship, the new America (Vol. 5). Los Angeles, CA: University of California Press.

Peek, L. A. (2011). Behind the backlash: Muslim Americans after 9/11. Philadelphia, PA: Temple University Press.

Puar, J. K. (2007). Terrorist assemblages: Homonationalism in queer times. Durham, NC: Duke University Press.

Rana, J. (2011). Terrifying Muslims: Race and labor in the South Asian diaspora. Durham, NC: Duke University Press.

Sawyer, A. M. (2017, June 22). Who are the Kurds, and why are they in Nashville? Tennessian. Retrieved from https://www.tennessean.com/story/news/local/2017/06/2/who-kurds-and-why-theynashville/97706968/

Shankar, S. (2008). Desi land: Teen culture, class, and success in Silicon Valley. Durham, NC: Duke University Press.

Sheyholislami, J., \& Sharifi, A. (2016). "It is the hardest to keep": Kurdish as a heritage language in the United States. International Journal of the Sociology of Language, 2016(237), 75-98. doi: 0165$2516 / 5967405834$

Smith, G. G., \& Grodz, S. (Eds.) (2014). Religion, Ethnicity and Transnational Migration Between West Africa and Europe. Boston, MA: Brill.

Statistic Canada (2011). 2011 National Household Survey: Data tables. Retrieved from https://www 12.statcan.gc.ca/census-recensement/2016/dp-pd/prof/details/page.cfm?Lang=E\&Geo1=PR\& Code $1=01 \&$ Geo $2=$ PR $\&$ Code $2=01 \&$ Data $=$ Count $\&$ SearchText $=01 \&$ SearchType $=$ Begins $\&$ SearchP $\mathrm{R}=01 \& \mathrm{~B} 1=\mathrm{All} \&$ Custom $=\& \mathrm{TABID}=3$

Tarman, B. \& Gürel, D. (2018). Awareness of Social Studies Teacher Candidates on Refugees in Turkey, Journal of Social Studies Research, DOI: 10.1016/j.jssr.2016.11.001

Thangaraj, S. (2013). Competing masculinities: South Asian American identity formation in Asian American basketball leagues. South Asian Popular Culture, 11(3), 243-255. http://dx.doi.org/10.1080/14746689.2013.820482

Thangaraj, S. (2015a). Desi hoop dreams: Pickup basketball and the making of Asian American masculinity. New York, NY: NYU Press.

(2015b). “American Public Spaces and Gender: Muslim America, Sport, and Activism.” In Suad Joseph and Sarah Gualtieri, editors, Encyclopedia of Women in Islamic Cultures. Leiden: Brill.

U.S. Census Bureau. (2010). 2006-2010 American Community Survey selected population tables: Kurdish total population. Retrieved May 6, 2016, from factfinder.census.gov

Vang, C. Y. (2016). Hmong youth, American football, and the cultural politics of ethnic sports tournaments. In Asian American Sporting Cultures, Stanley, Thangaraj, Constancio Arnaldo, Jr., and Christina Chin (Eds.). New York, NY: New York University Press.

(2010). Hmong America: Reconstructing community in diaspora (Vol. 100). University of Illinois Press.

Verma, G. K., Kalekin-Fishman, D., \& Pitkänen, P. (2002). Education and immigration: Settlement policies and current challenges. London, England: Routledge.

Wang, Y. (2013). Between Islam and the American Dream: An immigrant Muslim Community in Post-9/11 America. New York, NY: Routledge.

Woofter, S. (2019). [Book Review]: Building Equity: Policies and Practices to Empower All Learners. American Journal of Qualitative Research, 3(1), 136-139. https://doi.org/10.29333/ajqr/5815

Yigit, I. H., \& Tatch, A. (2017). Syrian refugees and Americans: Perceptions, attitudes and insights. American Journal of Qualitative Research, 1(1), 13-31. 